\title{
STANDARD HETEROSIS ANALYSIS IN MAIZE HYBRIDS UNDER WATER LOGGING CONDITION
}

\section{Gayatri Kumawat*, Jai Prakash Shahi, Munnesh Kumar, Ashok Singamsetti, Manish Kumar Choudhary, Kumari Shikha}

Department of Genetics and Plant breeding, Institute of Agriculture Science, Banaras Hindu University, Varanasi-221005, India

Received - February 18, 2020; Revision - March 03, 2020; Accepted -March 26, 2020

Available Online - April 25, 2020

DOI: http://dx.doi.org/10.18006/2020.8(2).90.97

\section{KEYWORDS \\ Maize \\ Water logging condition \\ Standard heterosis and hybrids}

\begin{abstract}
Maize is one of the important food and forage crops with abundant natural diversity. Determination of heterosis in CIMMYT maize hybrids under water logging condition is necessary for their commercial exploitation. The synthetics and composites have contributed to maize production in India in the initial stages of maize improvement programme, of late, hybrids are playing a vital role due to their high yielding potential. Breeding of water logging tolerant maize varieties will likely boosts maize production beyond the present level. Data derived from current study were complied to determine standard heterosis and identify high yielding hybrids. Among the tested 55 maize hybrids, the maize hybrids, namely, ZH17506, ZH17496 and VH11128 produced high heterosis which indicating that these hybrids are available for commercial cultivation. Maize hybrids that perform better than the checks could be used for release as hybrid variety after re-evaluation in multi-location trials.
\end{abstract}

* Corresponding author

E-mail: kumawatgayatri10@gmail.com (Gayatri Kumawat)

Peer review under responsibility of Journal of Experimental Biology and Agricultural Sciences.

Production and Hosting by Horizon Publisher India [HPI] (http://www.horizonpublisherindia.in/).

All rights reserved.
All the articles published by Journal of Experimental Biology and Agricultural Sciences are licensed under a Creative Commons Attribution-NonCommercial 4.0 International License Based on a work at www.jebas.org.

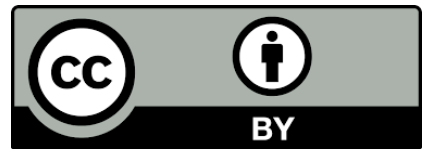




\section{Introduction}

Maize (Zea mays L.) is one of the most important field crops cultivated in India to ensure food security. Maize contributes the greatest share of production and consumption together with other major cereal crops, such as wheat, rice and Sorghum. Among the cereal crops, maize ranks third in area coverage and total annual production and productivity in India (Economic Survey 2015-16, MoA and FW, GOI). Globally maize covers an area of 178 million hectares with a production of 978.1 million tonnes (USDA, 2014$15)$ and Indian maize occupies an area of 9.2 million hectares with a production of 22.99 million tonnes (Indiastat.com, 2014-15) and productivity of $2583 \mathrm{~kg}$ ha-1. Initially synthetic and composite have contributed to maize production in India but now heterosis breeding play a key role due to their high yielding potential.

Generally, heterosis is an important trait used by breeders to evaluate the performance of offspring in relation to their parents. It estimates the enhanced performance of hybrids as compared to their parents. Often, the superiority of $F_{1}$ is estimated over the average of the two parents, or the mid parent or standard check (Shushay, 2014). Heterosis played an important role in maize breeding and selection of heterosis is dependent on level of dominance and differences in gene frequency. The manifestation of heterosis depends on genetic divergence of the two parental varieties (Hallauer \& Miranda, 1988). Heterosis is manifested as an increase in vigor, size, growth rate, yield or other characteristics. But in some cases, the hybrid may be inferior to the weaker parent, which is also considered as heterosis. That means heterosis can be positive or negative (Ram Reddy et al., 2015; Shah et al., 2016). The interpretation of heterosis depends on the nature of trait under study and the way it is measured.

The low grain yield can be attributed to a number of constraints which include biotic stress and abiotic stress. Unlike wetland crops, maize plants do not have a gaseous exchange system between aboveground plant parts and inundated roots under water lodging conditions. Therefore, excess soil moisture will results in anoxic soil condition for maize crop. Therefore, breeding of water logging tolerant maize varieties will likely boosts maize production beyond the present level (Kaur et al., 2019). Progress in different discipline of plant breeding for increased resistance for biotic and abiotic stress depends predominantly on the extent of heterosis present in germplasm. So the present investigation conducted to exploit standard heterosis to select best water logging resistance hybrid.

\section{Materials and Methods}

\subsection{Estimation of mean performance and heterosis}

This experimental study was carried out during crop season Kharif 2017 in alpha lattice design with two replications at the Agriculture
Research Farm of Banaras Hindu University, Varanasi, UP, India. The experiment genotypes comprised of 55 maize genotypes in which two standard checks (900MG from Monsanto and P3502 from Pioneer) and 53 maize hybrids were obtained from CIMMYT (International Maize and Wheat Improvement Center, Mexico) germplasm under the project- "Climate Resilient Maize for Asia (CRMA)". Each hybrid was planted in a single row of 3 meters in length with a spacing of row to row $60 \mathrm{~cm}$ and plant to plant $25 \mathrm{~cm}$. Water logging stress was imposed at $\mathrm{V}_{6}-\mathrm{V}_{7}$ growth stage/ knee height stage of crop growth (35 days after sowing). Draining out of excess water was done on seventh day (Zaidi et al., 2016). The crop was raised as per the recommended agronomic package of practices. The observations were recorded for fifteen characters viz. pre harvest data like-number of nodes bearing brace roots, number of surface roots, days to 50 percent anthesis, days to 50 percent silking, plant height $(\mathrm{cm})$, ear height $(\mathrm{cm})$ and post harvest data like-ears per plot, grain weight $(\mathrm{t} / \mathrm{h})$, plant population, ear length $(\mathrm{cm})$, ear diameter $(\mathrm{cm})$, number of kernel rows per ear, number of kernels per row, 100 seed weight $(\mathrm{g})$ and yield per plant $(\mathrm{g})$. The statistical analysis of data based on the mean value of recorded observations on five random plant basis was done.

Standard heterosis was estimated for grain yield per plant as deviation of F1 hybrid from the check included in the trial. It is expressed as percentage superiority over standard check. Standard heterosis was calculated for those traits that showed statistically significant differences among genotypes as suggested by Falconer \& Mackay (1996). These were computed as percentage increase or decrease of the cross performances over best standard check as follows.

$$
\text { Standard heterosis }(\mathrm{SH})=\frac{\mathrm{F} 1-\text { Check }}{\text { Check }} \times 100
$$

Where, $\mathrm{F}_{1}=$ mean value of $\mathrm{F}_{1} ; \mathrm{SH}=$ mean value over replication of the local commercial check

\subsection{Test of significance}

The significance of heterosis was tested by using ' $t$ ' test as suggested by Snedecor \& Cochran (1989) and Paschal \& Wilcox (1975).

$$
\begin{aligned}
& \mathrm{SE}(\mathrm{d})=\sqrt{\frac{2 \mathrm{MSE}}{\mathrm{r}}} \\
& \mathrm{t}=\frac{\mathrm{F} 1-\text { standard Check }}{\mathrm{SE}(\mathrm{d})}
\end{aligned}
$$

Where, $S E(d)$ is standard error of the difference; MSE is error mean square and $r$ is number of replications and calculated $t$ value was compared against the tabulated $t$-value at degree of freedom for error.

\section{Results and Discussion}

\subsection{Mean performance of genotypes}

The mean performances of the genotypes (the 53 hybrid progenies and two standard checks) across site are given in Table 1. Yield 


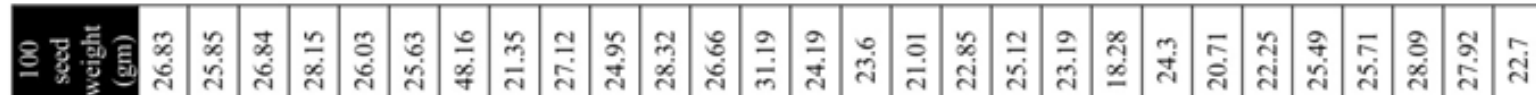
产 믈 팰

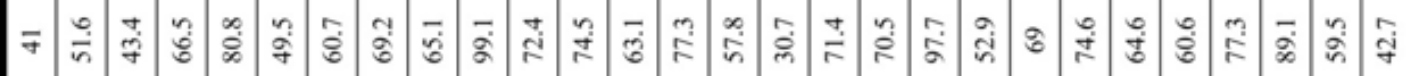
然害言

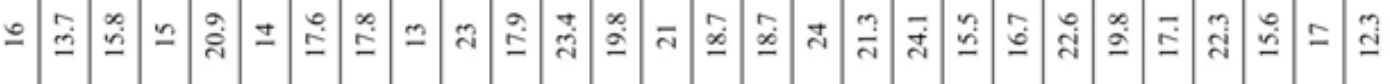
蜄言点

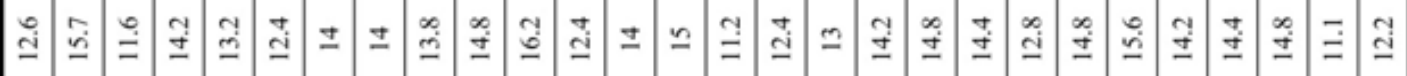

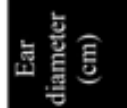

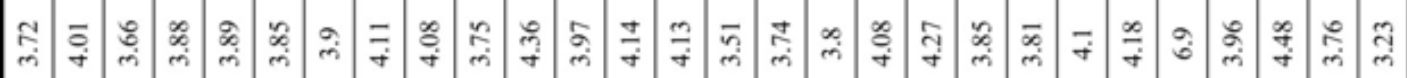
를 흘

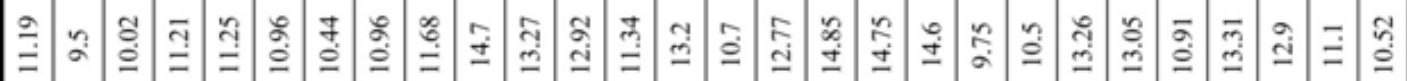

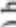

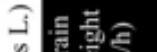

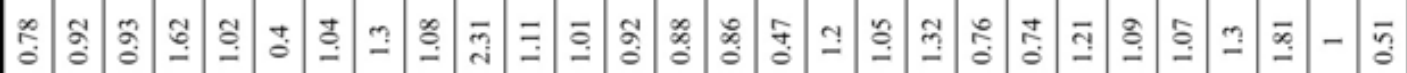
율

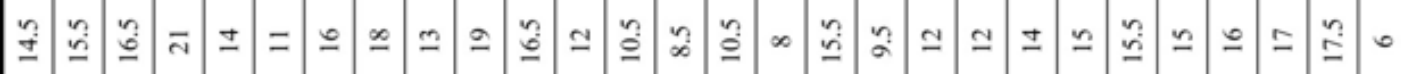

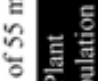
这部

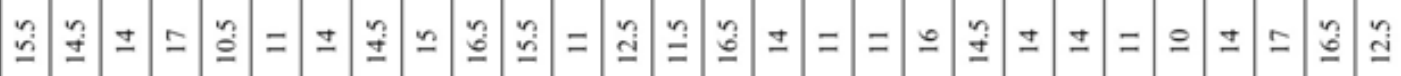

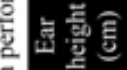

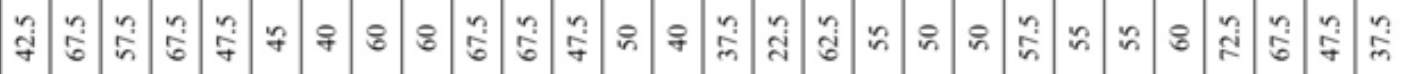

$\sum$

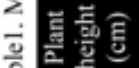

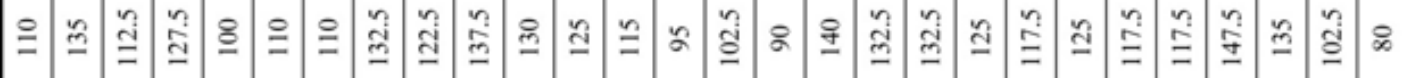

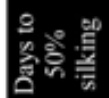
को

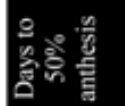
n.

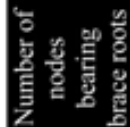

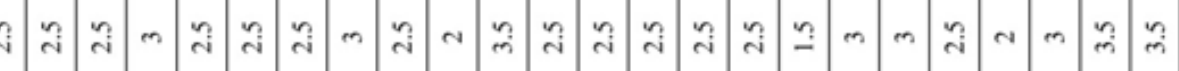

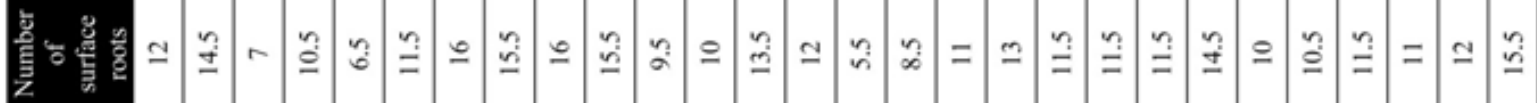
产

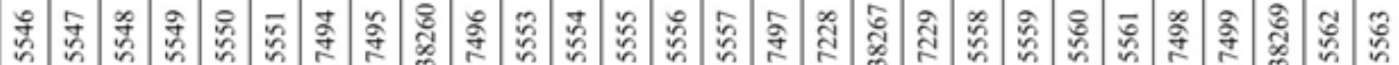

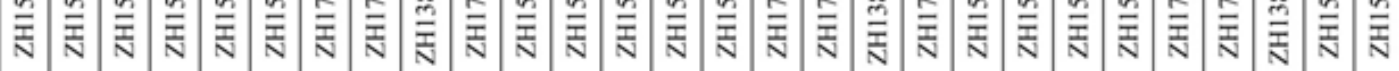

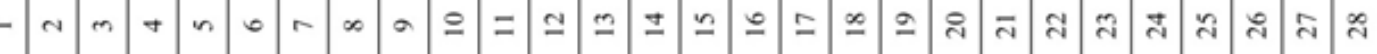




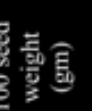

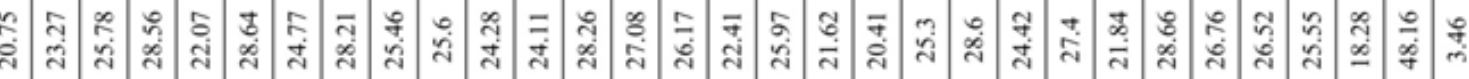

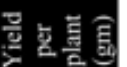

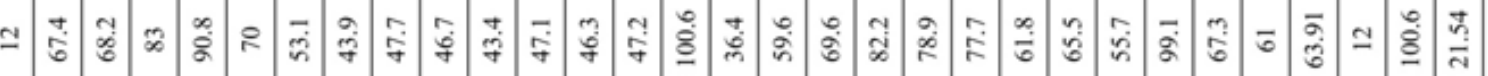

咅竞言

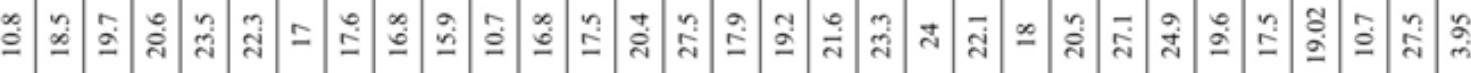

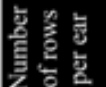

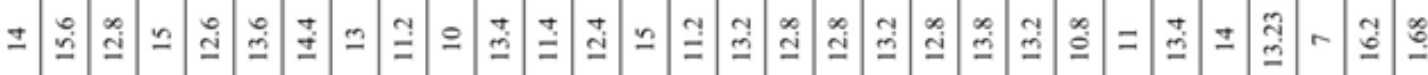

虚旁言

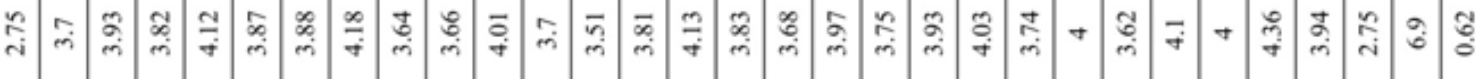

彭言

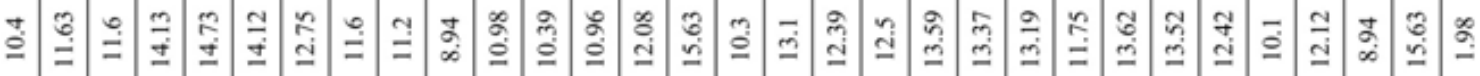

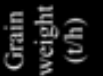

ণิ

总妾兽

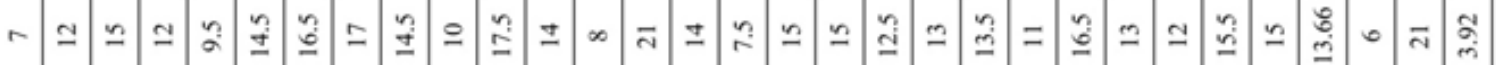

善言

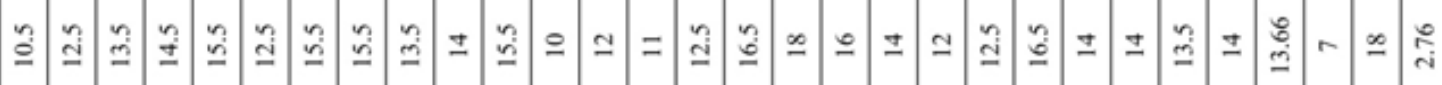

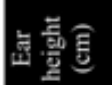

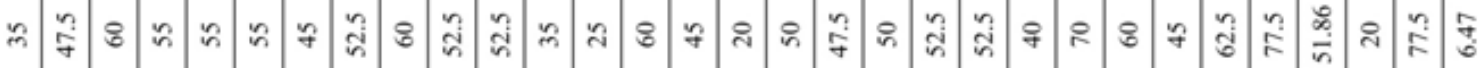

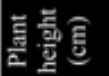

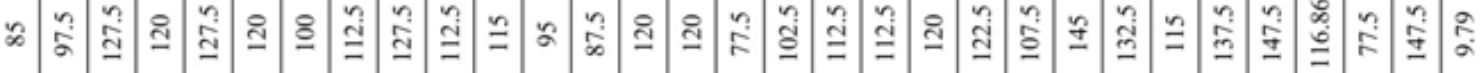

突高望

תู

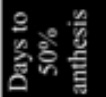

8 管

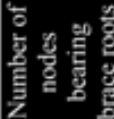

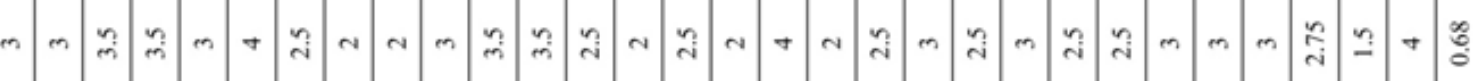

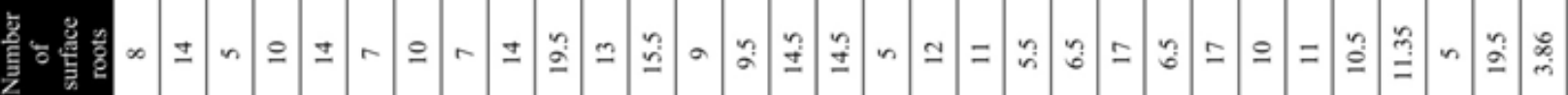

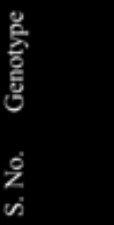

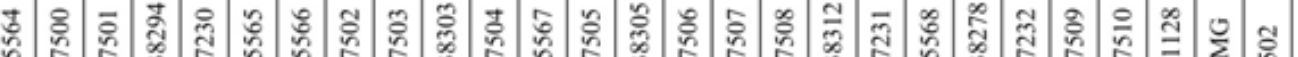

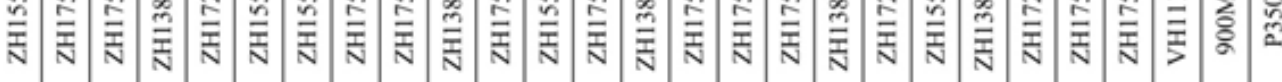

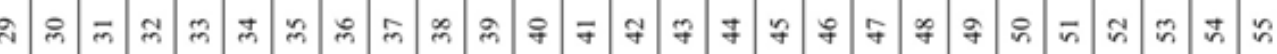

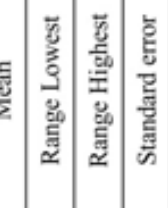

Journal of Experimental Biology and Agricultural Sciences 
per plant was recorded with a range of $12.00 \mathrm{~g}$ (ZH15564) to $100.00 \mathrm{~g}$ (ZH15506). Among the tested hybrids, ZH15506 yielded higher than $900 \mathrm{MG}$ check $(67.3 \mathrm{~g})$. The presence of crosses having mean values better than the standard checks indicate the possibility of obtaining good hybrid (s) for future use in breeding program or for commercial use general mean was observed $63.9 \mathrm{~g}$. Number of surface roots ranged from 5 (ZH17501, ZH17508) to 19.5 (ZH138303) with general mean 11.34 surface root per plant. Number of nodes bearing brace roots were recorded with a class from 1.50 (ZH15559) to 4.10 (ZH15560) with an average mean of 2.75 .

The number of days to $50 \%$ anthesis and days to $50 \%$ silking classified from 56.00 (ZH138260) to 68.50for (ZH15565) and 57.40 (ZH15547) to 68.5 (ZH15565) coupled with a general mean of 61.07 and 62.30 days respectively among 55 maize genotypes studied. Most of the crosses showed longest number of days to anthesis and silking. This shows that it might be because of late crosses in these genotypes. Late maturing hybrids are important in the breeding programs for development of high yielding hybrids in areas that receive sufficient rain fall (Hosana et al., 2015). Further evaluation and recommendation of this group of materials should be based on agro-ecological suitability.

At maturity, plant height and ear height mean value of different genotypes arranged from $77.50 \mathrm{~cm}$ (ZH17507) to $147.50 \mathrm{~cm}$ (ZH17499, P3502) and from $20.00 \mathrm{~cm}$ (ZH17507) to $77.50 \mathrm{~cm}$ (P3502) with an average mean of $116.8 \mathrm{~cm}$ and $51.86 \mathrm{~cm}$ respectively. In line with these finding, Hosana et al. (2015) reported higher grain yield from taller plants; this could be attributed to high photosynthetic products accumulation during long period for grain filling.

Plant population ranged from 7.00 (ZH15564) to 18.00 (ZH138312) with an average mean of 13.60. Ear per plots ranged from 6.00 (ZH17497) to 21.00(ZH15563) with an average mean of 13.66. Grain weight (weighing the total ears in a plot and later converted in to tones per hectors) was varied from 0.24 (ZH15564) to 2.30 ton per hectare (ZH17496). Ear length and ear diameter was recorded with a range of ranged from $8.90 \mathrm{~cm}$ (ZH15561) to $15.60 \mathrm{~cm}$ (ZH17232) and $2.70 \mathrm{~cm}$ (ZH15564) to $6.90 \mathrm{~cm}$ (ZH17498) with an average mean of $12.12 \mathrm{~cm}$ and 3.90 $\mathrm{cm}$ respectively. The number of kernel rows per ear ranged from 7.00 to 16.20 with the mean 13.20 . The lowest rows were found in ZH15564 whereas the highest was found in ZH15553. The number of kernels per row for 55 maize genotypes varied from 10.70 (ZH15504) to 27.50 (ZH17506) with a general mean 19.01. Wait for 100 grains for all 55 genotypes ranged from $18.27 \mathrm{~g}$ in ZH15558 to $48.15 \mathrm{~g}$ in ZH17494 genotype. The observed mean was $25.5 \mathrm{~g}$. The genotypes showing high mean value for post harvest yield attributing traits under water logging condition can be exploited further for high soil moisture resistance genotype development (Zaidi et al., 2010; Shushay, 2014;).

\subsection{Standard heterosis}

The estimates of standard heterosis over the standard check 900MG were computed for grain yield and yield related traits and presented in Table 2. As the mean value of yield per plant higher for $900 \mathrm{MG}$ check than P3502 check, so $900 \mathrm{MG}$ check exploit as standard check in this experiment. Three hybrids showed positive and significant heterosis to $900 \mathrm{MG}$ standard check for grain yield per plant. Standard heterosis for grain yield per plant ranged from 82.17 (ZH 15564) to $49.48 \%$ (ZH17506). ZH17496 and VH11128 $(47.25 \%)$ exhibited positive standard heterosis to the standard check. Positive heterosis for this trait indicates increased yield advantage over the existing standard check. Maize hybrids that perform better than the checks could be used for release as hybrid variety after verification.

Standard heterosis for days to $50 \%$ anthesis and silking ranged from -9.68 to $10.48 \%$ and -4.88 to $11.38 \%$ to $900 \mathrm{MG}$ respectively. Three hybrids showed positive and significant heterosis for these traits to check indicating that these hybrids were late maturing as compared to the checks. Heterosis in the negative direction for these traits indicates earliness of the crosses over the standard checks so negative heterosis is desirable for them. Significant negative heterosis for days to tasseling was observed in ZH15546, ZH138260, ZH15558, ZH17502 and ZH17504 crosses. Earlier Amiruzzaman et al. (2013) and Bello \& Olawuyi (2015) reported negative heterosis for these traits in maize.

Standard heterosis for surface and brace roots showed three and two genotypes positively significant respectively. The positive heterosis in these traits indicates desirable hybrids with more water logging resistance. Positively significant genotypes for plant height and ear height indicated desirable hybrids with more photosynthetic efficiency. Similarly post harvest data (yield data) indicates viz- ear length, ear diameter, number of rows per ear, number of kernels per row and 100 seed weight showed positive significant heterosis for those hybrids which can be used for commercialization of hybrids (Singh \& Jha 2007; Ulaganathan et al., 2015).

\section{Conclusion}

Three hybrids (ZH17506, ZH17496 and VH11128) showed positive and significant heterosis to $900 \mathrm{MG}$ standard check for grain yield per plant. Maize hybrids that perform better than the checks could be used for release as hybrid variety after reevaluation in multi-location trials. 


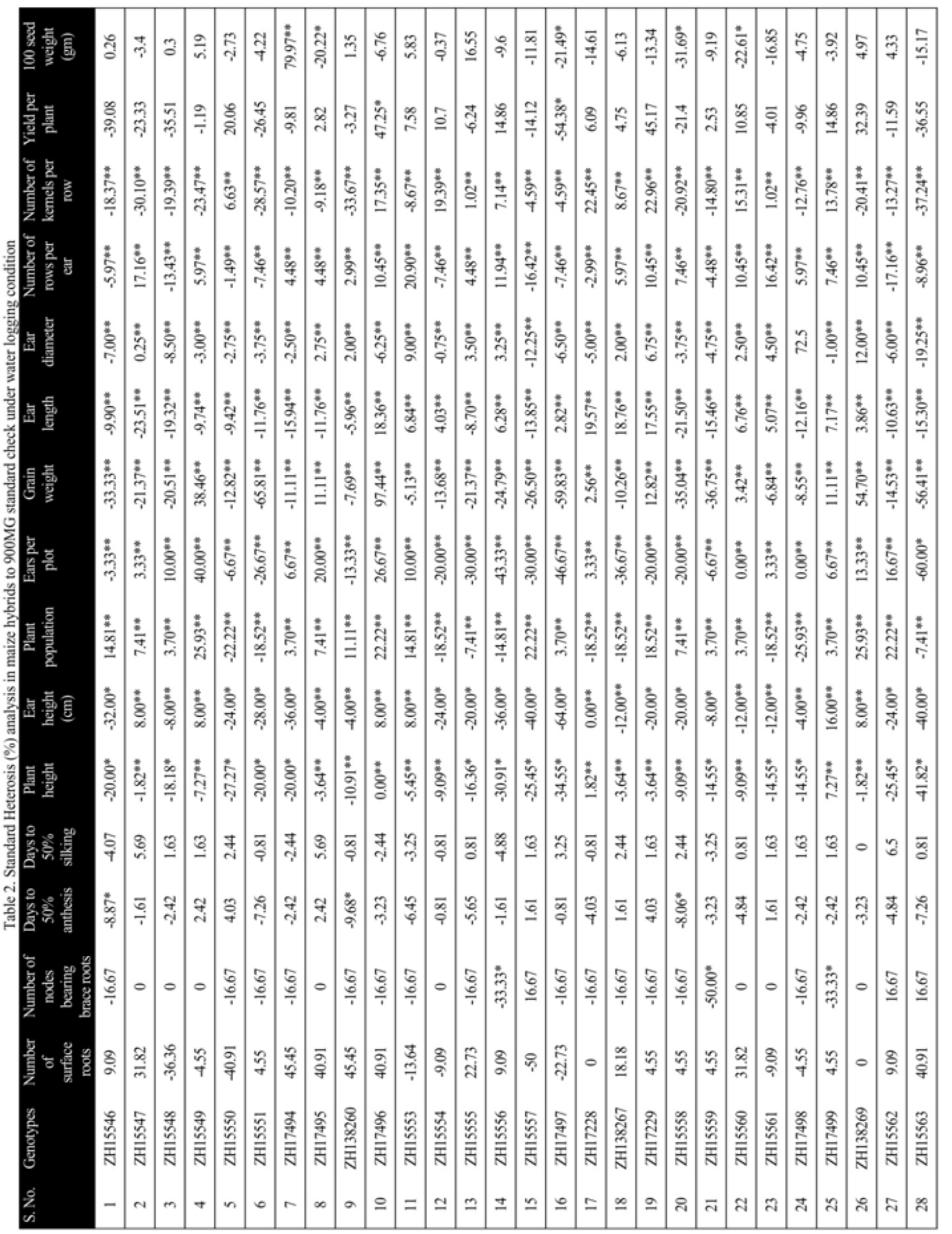

Journal of Experimental Biology and Agricultural Sciences http://www.jebas.org 


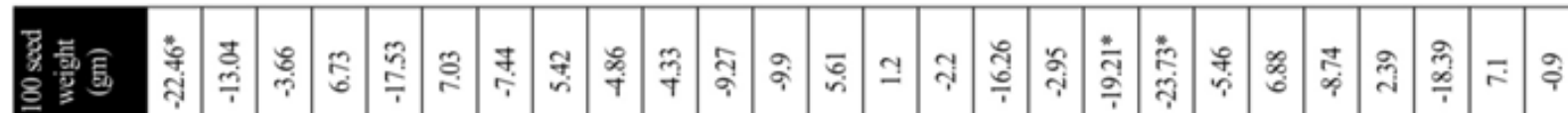

然直

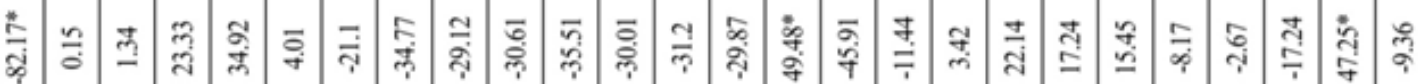
항

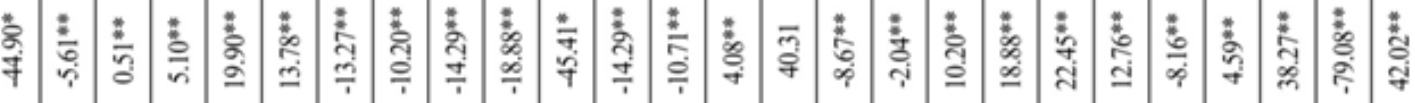
离部

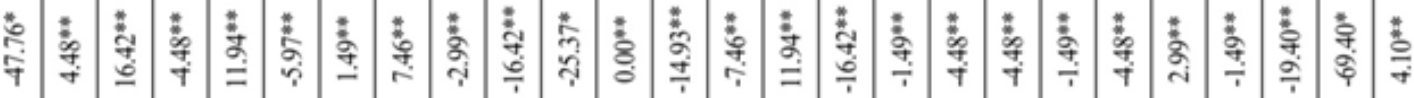

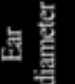

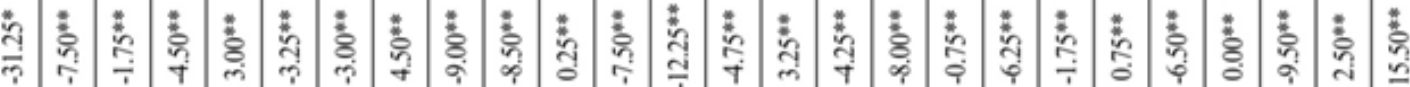
点㽞

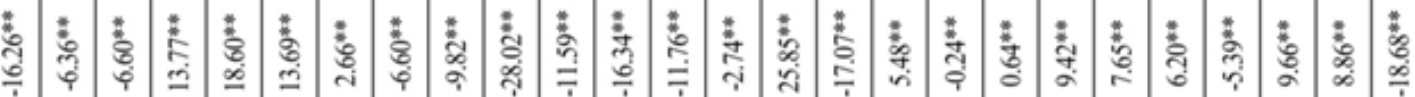
叟憘

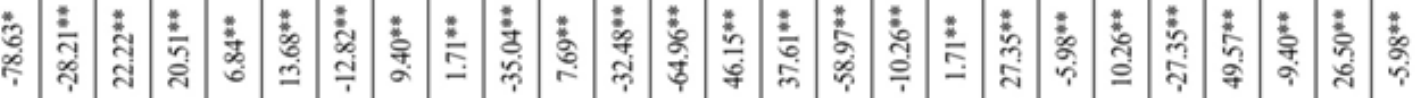

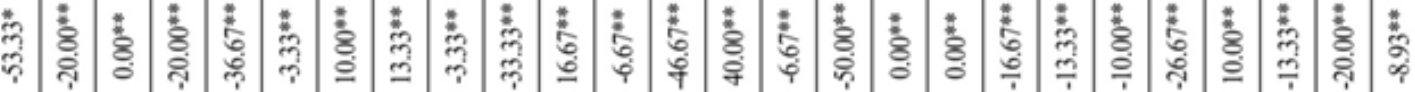
黄

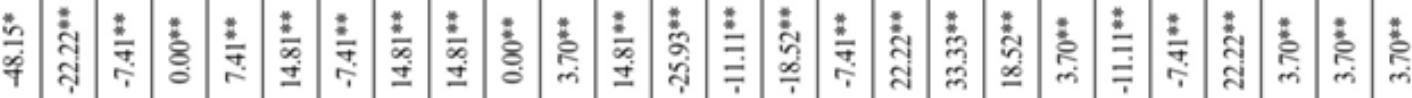

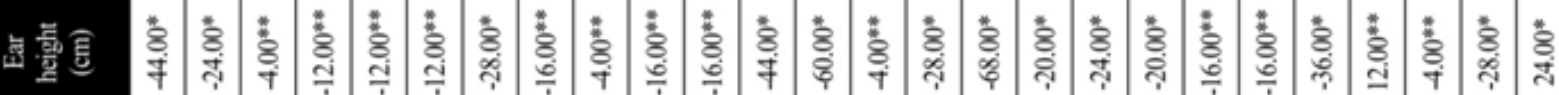

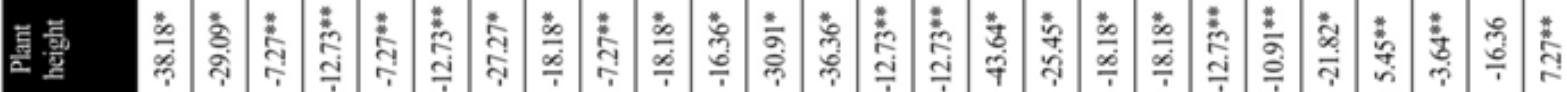

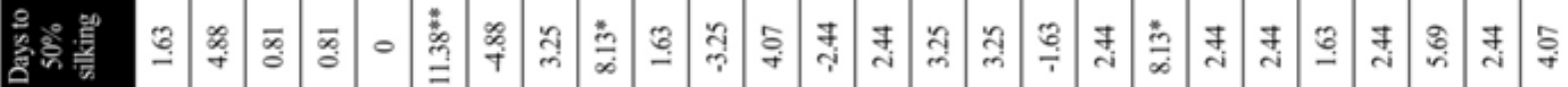

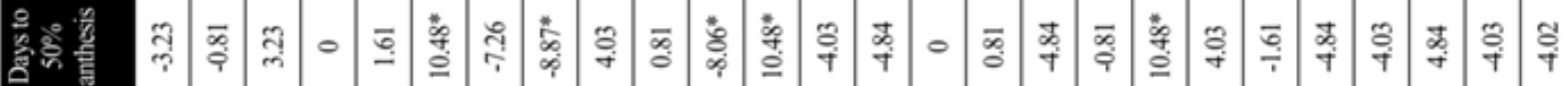

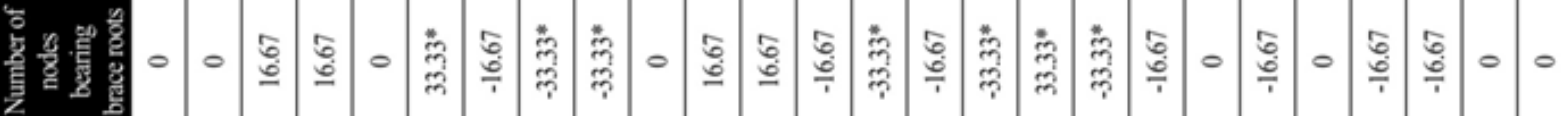

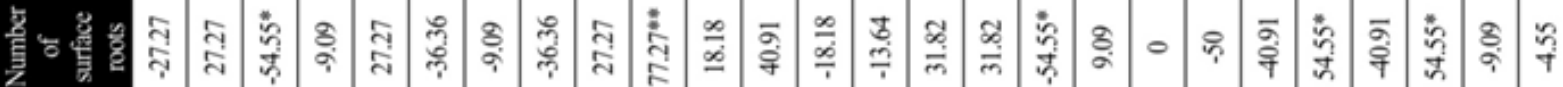

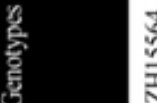

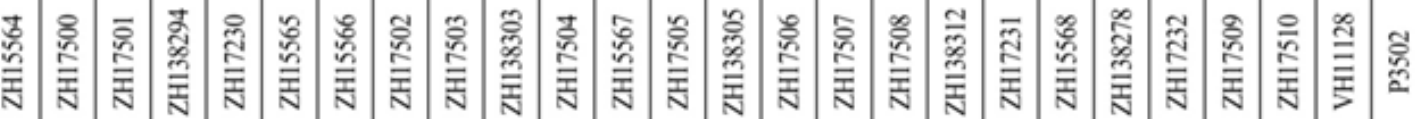
$\sin \frac{8}{2}$

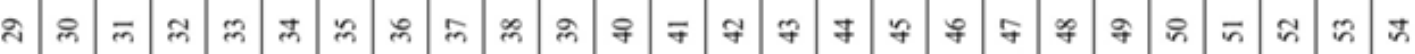




\section{Acknowledgements}

We would like to express our sincere appreciation to the CIMMYT Hyderabad and Institute of Agriculture Sciences Banaras Hindu University.

\section{Conflict of Interest}

Authors would hereby like to declare that there is no conflict of interests that could possibly arise.

\section{References}

Amiruzzaman M, Islam MA, Hasan L, Kadir M, Rohman MM (2013) Heterosis and combining ability in a diallel among elite inbred lines of maize (Zea mays L.). Emirates Journal of Food and Agriculture 25: 132-137.

Bello OB, Olawuyi OJ (2015) Gene action, heterosis, correlation and regression estimates in developing hybrid cultivars in maize. Tropical Agriculture 92: 102-117.

Economic Survey (2016). Economic Survey 2015-16 Retrieved from idiabudget.nic.in/es2015-16/ estat1.pdf access on 18 September, 2019.

Falconer DS, Mackay TFC (1996) Introduction to Quantitative Genetics, $4^{\text {th }}$ edn. Longman, London.

Hallauer AR, Miranda JB (1988) Quantitative genetics in maize breeding. Iowa State Univ. Press, Ames. Quantitative genetics in maize breeding. 2nd ed. Iowa State Univ. Press, Ames.

Hosana GC, Alamerew S, Tadesse B, Menamo T (2015) Test cross performance and combining ability of maize (Zea mays L.) inbred lines at Bako, Western Ethiopia. Global Journal (USA) 15: 24.

Indiastat Agriculture production (2014) Indiastat Agriculture production 201315 available on http://www.indiastat.com access on 18 September, 2019.

Kaur G, Zurweller B, Motavalli PP, Nelson KA (2019) Screening Corn Hybrids for Soil Waterlogging Tolerance at an Early Growth
Stage. Agriculture 9: 33.

Paschal EH, Wilcox JR (1975) Heterosis and combining ability in exotic soybean germplasm. Crop Science 15: 344-349.

Ram Reddy V, Farzana zabeen, Sudarshan MR (2015) Heterosis studies in diallel crosses of maize for yield and yield attributing traits in maize over locations. International Journal of Agricultural, Environment and Biotechnology 8: 271-283.

Shah RT, Prasad K, Kumar P (2016) Maize-A potential source of human nutrition and health: A review. Cogent Food and Agriculture 2: 1166995.

Shushay WA (2014) Standard heterosis of maize (Zea mays L.) inbred lines for grain yield and yield related traits in central Rift Valley of Ethiopia. Journal of Biology, Agriculture and Healthcare 4: 31-37.

Singh SP, Jha PB (2007) Heterotic potential of winter maize hybrids for yield attributing traits under variable moisture condition. Journal of Applied Bioscience 33: 1-7.

Snedecor, GW, Cochran, WG (1989) Statistical Methods. $8^{\text {th }}$ ed. Lowa State University press. Ames. IA.

Ulaganathan V, Vinoth R, Baghyalakshmi K, Chimili SR, Gurusamy A (2015) Standard heterosis for grain yield and other agronomic characters in maize (Zea mays L.) under normal and moisture stress conditions. An International Quarterly Journal of Life Science 10: 1251-1253.

USDA (2014) World Agricultural Production. 2013-2014. Available on www.usda.gov access on 19 September, 2019.

Zaidi PH, Maniselvan P, Srivastava A, Yadav P, Singh RP (2010) Genetic analysis of water-logging tolerance in tropical maize (Zea mays L.). Maydica 55: 17-26.

Zaidi PH, Vinayan MT, Seetharam K (2016) Phenotyping for abiotic stress tolerance in maize: Waterlogging stress. A field manual. CIMMYT: Hyderabad, India. 